\title{
Concentration levels and spatial distribution of sulphur and metals in fine-grained sediments in western Finland
}

\author{
Mats Åström and Kristoffer Rönnback \\ Department of Biology and Environmental Science, Kalmar University, SE-391 82 Kalmar, Sweden, \\ e-mail: kristoffer.ronnback@hik.se
}

\begin{abstract}
On the coastal plains of Finland, widespread Holocene marine and lacustrine sediments have developed into acid sulphate soil as a result of extensive artificial drainage for agricultural purposes. This has caused a variety of environmental problems. The aim of this study was to determine the concentration levels and spatial distribution of sulphur, carbon and metals [titanium, vanadium, chromium, manganese (Mn), iron, cobalt $(\mathrm{Co})$, nickel $(\mathrm{Ni})$, copper $(\mathrm{Cu})$, zinc $(\mathrm{Zn})]$ in these sediments, in order to increase the geochemical understanding of the parent materials from which acid sulphate soil develops. Sediment samples were collected at 317 sites from a depth of 1.5-3 m. While the sediments have high $\mathrm{S}$ (sulphide) concentrations (median $=0.54 \%)$ and thus a strong acidification potential, they carry transition metals mainly in smallsized silicates close to "background concentrations" far below contamination limits. The previously documented extensive release of $\mathrm{Co}, \mathrm{Cu}, \mathrm{Mn}, \mathrm{Ni}$ and $\mathrm{Zn}$ from oxidised and acidified layers of these sediments (i.e. acid sulphate soil) is thus not explained by anomalously high natural or anthropogenic metal concentrations of the soils/sediments, but by an inherent highly mobile metal pool. Spatial-distribution maps highlight areas of elevated S and Mn concentrations, where it is likely that ditching and subsequent oxidation will result in an exceptionally large release of protons and Mn respectively.
\end{abstract}

Key words: sulphur, transition metals, acid sulphate soil, Holocene sediments, metal leaching, soil acidification

\section{Introduction}

On the coastal plains of Finland, large areas are covered with Holocene marine sediments that were deposited in post-glacial waters and now outcrops inland as the shoreline has regressed due to iso- static land uplift. These sediments have an aluminosilicate matrix derived largely from glacial till (Öborn 1991), they have variable amounts (up to ca. $2 \%$ ) of disseminative secondary sulphide minerals (Papunen 1968, Georgala 1980), and they are low in carbonate due to the mostly Proterozoic granitoidic bedrock of the area (Lehtinen et al. 
Vol. 14 (2005): 14-23.

1998). Scattered intercalative patches of lake sediments have similar physicochemical characteristics.

These marine and lacustrine sediments are almost entirely cultivated because their high nutrient content and fine grain size (clay-silt) are advantageous for such activities. However, because these sediments have a poor natural drainage, which is a disadvantage for the agricultural activities, they have been artificially drained over the last two centuries. Prior to the 1970s drainage was in the form of open surface ditches, while in the last few decades it has largely changed to efficient networks of subsurface pipes at depths of 100-110 cm. A negative side effect of these practices is that when the ground-water table drops after the drainage, the penetrating $\mathrm{O}_{2}$ oxidises the naturally occurring (iron) sulphides resulting in sulphuric acid formation and development of severely acidic ( $\mathrm{pH} 2.5-$ 4.0) soils (Wiklander and Hallgren 1949, Wiklander et al. 1950, Yli-Halla 1997). These soils are classified as Sulfic Cryaquepts or Typic Sulfaquepts but commonly referred to as acid sulphate (AS) soil (Erviö and Palko 1984, Yli-Halla 1997, Yli-Halla et al. 1999). Similar soils are widely spread also in coastal areas elsewhere, e.g. in W and E Africa, N South America, S North America, Australia, and S and SE Asia (Kawalec 1973). During snow melting and heavy rains, the AS soils are extensively leached resulting in $\mathrm{pH}$ values between 3 and 4 and strongly elevated concentrations of a number of major and trace metals in the receiving streams (Palko and Yli-Halla 1993, Weppling 1993, Åström and Åström 1997, Edén et al. 1999, Weppling et al. 1999, Åström and Spiro 2000). This in turn has negative effects on the hydrobiology (Kjellman and Hudd 1996).

The aim of this study was to determine the concentration levels and spatial distribution of sulphur, carbon and first-row transition metals in marine and lacustrine sediments on the coastal plains of Finland. The focus on these particular metals is due to the fact that they are both agriculturally and environmentally important, and that among them the mobility upon sediment oxidation (i.e. AS soil development) is highly variable: cobalt (Co), copper $(\mathrm{Cu})$, manganese $(\mathrm{Mn})$, nickel $(\mathrm{Ni})$ and zinc
(Zn) are mobile and abundantly leached while chromium $(\mathrm{Cr})$, iron $(\mathrm{Fe})$, titanium (Ti) and vanadium (V) are not (Lahermo et al. 1996, Åström and Åström 1997, Åström and Spiro 2000). The study is based partly on new interpretations of data earlier presented by Åström and Björklund (1997) in their paper on the abundance and oxidative mobility of $\mathrm{S}$ and metals in these sediments, and partly on new physicochemical analyses.

The ultimate goal is to produce geochemical maps of the AS soils throughout the coastal plains. However, this will be a difficult and expensive task because, first, the existing pedological and geological maps do not identify AS soils, second, the current and potential leaching of AS soils will vary considerably among the numerous locations and, third, the complex element (re)distribution in the AS soil horizons makes geochemical characterisation demanding. Prior information on the parent sediments, which are practically chemically inert and thus easier to interpret from a geochemical point of view, is thus desirable. In this paper, such information is presented for the sediments of western central Finland, i.e. an area where AS soils are particularly abundant and environmentally unfriendly.

\section{Material and methods}

The study area is located on the coastal plains of central Finland. An approximately $20 \mathrm{~cm}$ vertical section of fine-grained sediment (either marine or lacustrine) was collected with an auger from the reduced zone at a total of 317 sites (Fig. 1). The depth from which the samples were taken varied between 1.5 and $3 \mathrm{~m}$. The reasons as to why the sampling-site pattern is not uniform but rather traverse, random and locally clustered (Fig. 1) is that, first, a majority of the fine-grained sediments are located along river valleys, second, only easily accessible sites (close to roads) were chosen and, third, the sampling density was increased in some areas for the purpose of other parallel studies. At sampling, the sediment was categorised, based on 
Åström, M. \& Rönnback, K. Concentration levels of sulphur and metals in fine-grained sediments

its overall appearance, either as a light (dominantly grey colour) or dark (dominantly black colour) sediment. The number of samples in each group was 161 and 156 respectively.

After drying in an oven at $50^{\circ} \mathrm{C}$, the samples were analysed for physicochemical properties in accredited commercial geochemical laboratories. Concentrations of $\mathrm{S}$ and $\mathrm{C}$ were determined by pyrolysis of samples at $850^{\circ} \mathrm{C}$ and detection of gas with IR detector (Leco), and concentrations of firstrow transition metals ( $\mathrm{Ti}, \mathrm{V}, \mathrm{Cr}, \mathrm{Mn}, \mathrm{Fe}, \mathrm{Co}, \mathrm{Ni}$, $\mathrm{Cu}, \mathrm{Zn}$ ) were determined with ICP-AES after a partial digestion of the samples in 3:1:2 $\mathrm{HCl}$ : $\mathrm{HNO}_{3}: \mathrm{H}_{2} \mathrm{O}$ (aqua regia) at $95^{\circ} \mathrm{C}$ (Åström and Björklund 1997). Fifty randomly selected samples were analysed for the same suite of metals after a near total sample digestion by $\mathrm{HNO}_{3}-\mathrm{HClO}_{4}$-HF$\mathrm{HCl}$ (strong 4-acid digestion), and for grain-size distribution with a Sympatec Helos Vectra Laser Diffractometer after sample disintegration in sodium pyrophosphate and shaking for $20 \mathrm{~h}$. Randomly selected samples, prepared in duplicate and analysed independently and anonymously, were used to estimate the analytical precision according to the method proposed by Gill (1997). For the aqua regia leach (59 duplicates) and the strong 4acid digestion (10 duplicates) the precision was for $\mathrm{Ti} 4.6 \%$ and $6.7 \%$ respectively, $\mathrm{V} 3.9 / 4.7, \mathrm{Cr}$ 4.4/8.4, Mn 4.9/5.7, Fe 4.3/7.5, Co 9.5/10.6, Ni 7.1/3.8, $\mathrm{Cu}$ 8.0/8.7 and $\mathrm{Zn} 4.6 / 6.8$. For $\mathrm{S}$ and $\mathrm{C}(29$ duplicates) the precision was $10.8 \%$ and $3.8 \%$ respectively.

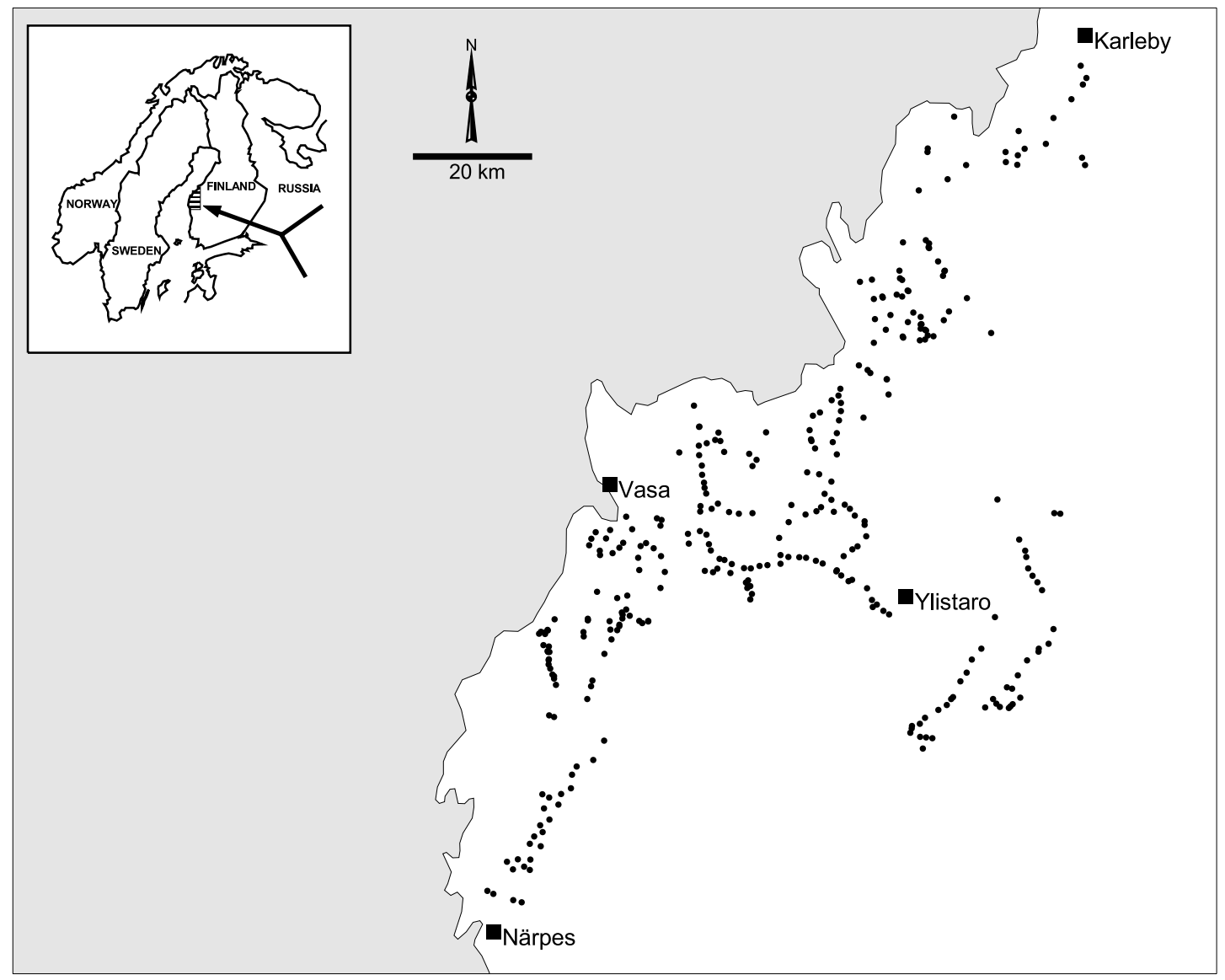

Fig. 1. The sampling sites $(\mathrm{n}=317)$ of fine-grained sediments (after Åström and Björklund 1997). 
Vol. 14 (2005): 14-23.

Glacial till samples collected at a frequency of 1 sample per $4 \mathrm{~km}^{2}$ (throughout the country) and analysed after an aqua regia digestion (Geological Survey of Finland, Geochemistry Department, regional geochemical till data) were used to investigate possible geochemical relationships between the till and the fine-grained sediments. For each sampling site of fine-grained sediment (Fig. 1), the nearest till sample was searched in the database. Omitting sites of fine-grained sediment located closer to another site of such sediment than to the nearest till site, gave a total of 258 pairs which were used in the statistical analyses. The maximum distance between two paired sampling sites was $5.4 \mathrm{~km}$, but for more than $90 \%$ of the pairs the intersite distance was $<2 \mathrm{~km}$ (Wik 2000).

Growing symbols and grey-scale colour maps were used to study the spatial distribution of element concentrations in the fine-grained sediments. For the colour maps, the sample data were interpolated to the grid $0.2 \times 0.2 \mathrm{~km}$ using an Inverse Distance Weighting (IDW) method with a fixed radius of $20 \mathrm{~km}$ and a power factor equal to 2 . The colour maps were made in order to get an overall picture of the spatial distribution of the element concentrations in the samples and in the area as a whole. It should be noticed that the fine-grained sediments do not cover the entire area.

\section{Results and discussion}

\section{Carbon}

The $\mathrm{C}$ concentrations in the 317 sediment samples were relatively low, i.e. the median and maximum concentrations were $1.4 \%$ and $4.0 \%$ respectively (Table 1). Previous studies show that the $\mathrm{C}$ is largely held in organic substances preserved in the sediments over the (short) pre-depositional period, and that carbonate concentrations are in general low (ca. $1-5 \%$ of the total C) as a result of limited limestone and dolomite occurrences in the underlying bedrock (Georgala 1980, Palko 1994). Consequently, the sediments have an overall low hydrogen-ion buffering capacity.

\section{Sulphur}

The $\mathrm{S}$ concentrations (median $0.54 \%$ and maximum $1.78 \%$ ) were relatively low as compared to corresponding concentrations in many similar sediments in tropical and subtropical areas (van Breemen 1973, Dent 1980). From an environmental point of view, however, the concentrations are high since it has been shown by an oxidation experi-

Table 1. Concentrations of elements in grey $(n=161)$, black $(n=156)$ and all the samples $(n=317)$ of fine-grained sediments collected in the study area, and in the fine-fraction $(<0.06 \mathrm{~mm})$ of till samples $(\mathrm{n}=1186)$ from the same area. The guideline values for contaminated soils are indicated.

\begin{tabular}{|c|c|c|c|c|c|}
\hline & $\begin{array}{l}\text { Fine-gra } \\
\text { grey } \\
\text { median }\end{array}$ & $\begin{array}{l}\text { ediments } \\
\text { black } \\
\text { median }\end{array}$ & $\begin{array}{l}\text { all } \\
\text { median }\end{array}$ & $\begin{array}{l}\text { all } \\
\text { maximum }\end{array}$ & $\begin{array}{l}\text { Contaminated soils }{ }^{1)} \\
\text { guideline values }\end{array}$ \\
\hline $\mathrm{Fe}, \%$ & 3.7 & 3.8 & 3.8 & 5.7 & - \\
\hline $\mathrm{C}, \%$ & 1.0 & 1.8 & 1.4 & 4.0 & - \\
\hline S, \% & 0.40 & 0.59 & 0.54 & 1.78 & - \\
\hline $\mathrm{Ti}, \%$ & 0.23 & 0.21 & 0.22 & 0.30 & - \\
\hline $\mathrm{Mn}, \mathrm{ppm}$ & 444 & 456 & 448 & 1147 & - \\
\hline $\mathrm{Zn}, \mathrm{ppm}$ & 91 & 90 & 90 & 142 & 700 \\
\hline $\mathrm{V}, \mathrm{ppm}$ & 52 & 50 & 50 & 76 & 500 \\
\hline $\mathrm{Cr}, \mathrm{ppm}$ & 49 & 47 & 48 & 76 & 400 \\
\hline $\mathrm{Cu}, \mathrm{ppm}$ & 28 & 26 & 27 & 65 & 400 \\
\hline $\mathrm{Ni}, \mathrm{ppm}$ & 33 & 31 & 31 & 58 & 200 \\
\hline $\mathrm{Co}, \mathrm{ppm}$ & 13 & 13 & 13 & 31 & 200 \\
\hline
\end{tabular}

\footnotetext{
1) Ministry of Social Affairs and Health (1994)
} 
Åström, M. \& Rönnback, K. Concentration levels of sulphur and metals in fine-grained sediments

ment in laboratory, that at $\mathrm{S}$ concentrations > $0.20 \%$ ( $78 \%$ of the sediment samples), severe acidity $(\mathrm{pH}<3.5)$ rapidly develops on oxidation (Åström and Björklund 1997). Hence, about $78 \%$ of the investigated samples can be considered as representing parent sediments of AS soils. While precise information on the distribution of S minerals in the sediments is unknown, disseminative secondary mono and disulphides are likely to predominate in most locations (Papunen 1968, Georgala 1980, Palko 1994).

At low and harmless S concentrations (< $0.20 \%)$ grey samples were dominating (60/71), while at elevated and harmful $\mathrm{S}$ concentrations (0.20-2.0\%) colour and concentrations were uncorrelated (Fig. 2). Hence, while the grey sediments had somewhat lower median S concentration (Table 1) and many of these had very low $S$ concentrations (Fig. 2), the high $\mathrm{S}$ concentrations of many other grey sediments excluded colour determination as an easy and rapid method to assess the potential environmental (acidification) threat of a particular sediment layer. However, if a sediment is black, there is a very high probability that it contains more than $0.20 \% \mathrm{~S}(145 / 156=93 \%$ of cases, Fig. 2) and thus will acidify upon drainage and oxidation.

The $\mathrm{S}$ and $\mathrm{C}$ concentrations were correlated (Fig. 2), which is a well known phenomenon (Berner 1984) explained by more extensive reduction of sea-water sulphate (and thus more abundant precipitation of metal sulphides) at high than low rates of deposition and preservation of organic matter in the sediment. Another characteristic feature in the correlation data was that the black sediments had higher $\mathrm{C}$ (organic matter) concentrations, as compared to the grey ones, at any given $\mathrm{S}$ concentration (Fig. 2). There is, however, no question that the black colour is caused by disseminative iron monosulphides and not by the organic molecules. Hence, the effect of elevated concentrations of organic material seems to be to make the conditions for precipitation and preservation of iron monosulphide more favourable.

There was a clear spatial pattern of the S concentrations, i.e. in the western central parts (wide area around the city of Vasa) many samples were

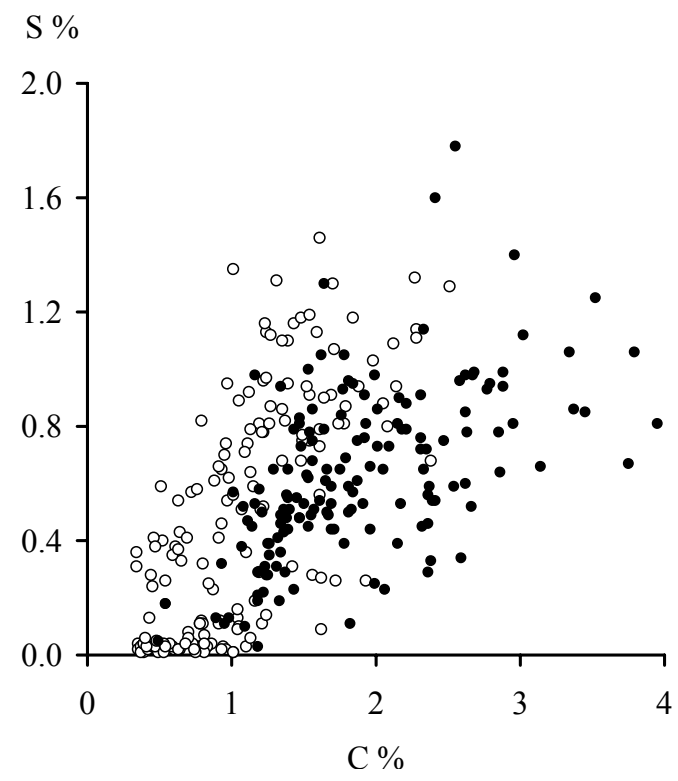

Fig. 2. Plot of carbon versus sulphur concentrations for 161 grey-coloured (open circles) and 156 black-coloured (filled circles) sediments.

high in $\mathrm{S}$ resulting in a distinct dark colour (high concentrations) on the map (Fig. 3). Hence, the sediments found within this area overall had higher $\mathrm{S}$ concentrations than elsewhere, and are thus more likely to develop into (or have already developed into) severely acidic and problematic AS soils. However, also outside this area, a dominating part of the samples had $\mathrm{S}$ concentrations above the critical $0.20 \% \mathrm{~S}$ (Fig. 3). Therefore, AS soils (relict, current or potential) exist abundantly also here, which is in fact known from previous field observations by local farmers, environmental authorities and researchers.

\section{Metals}

The aqua regia leach dissolved $\mathrm{Cu}$ and $\mathrm{Co}$ almost entirely (97\% and $100 \%$ respectively), the metals $\mathrm{Fe}, \mathrm{Ni}$ and $\mathrm{Zn}$ to a large extent (83-86\%), and also more than half of the Ti, V, Cr and Mn (57-69\%). These data are in agreement to those reported for 


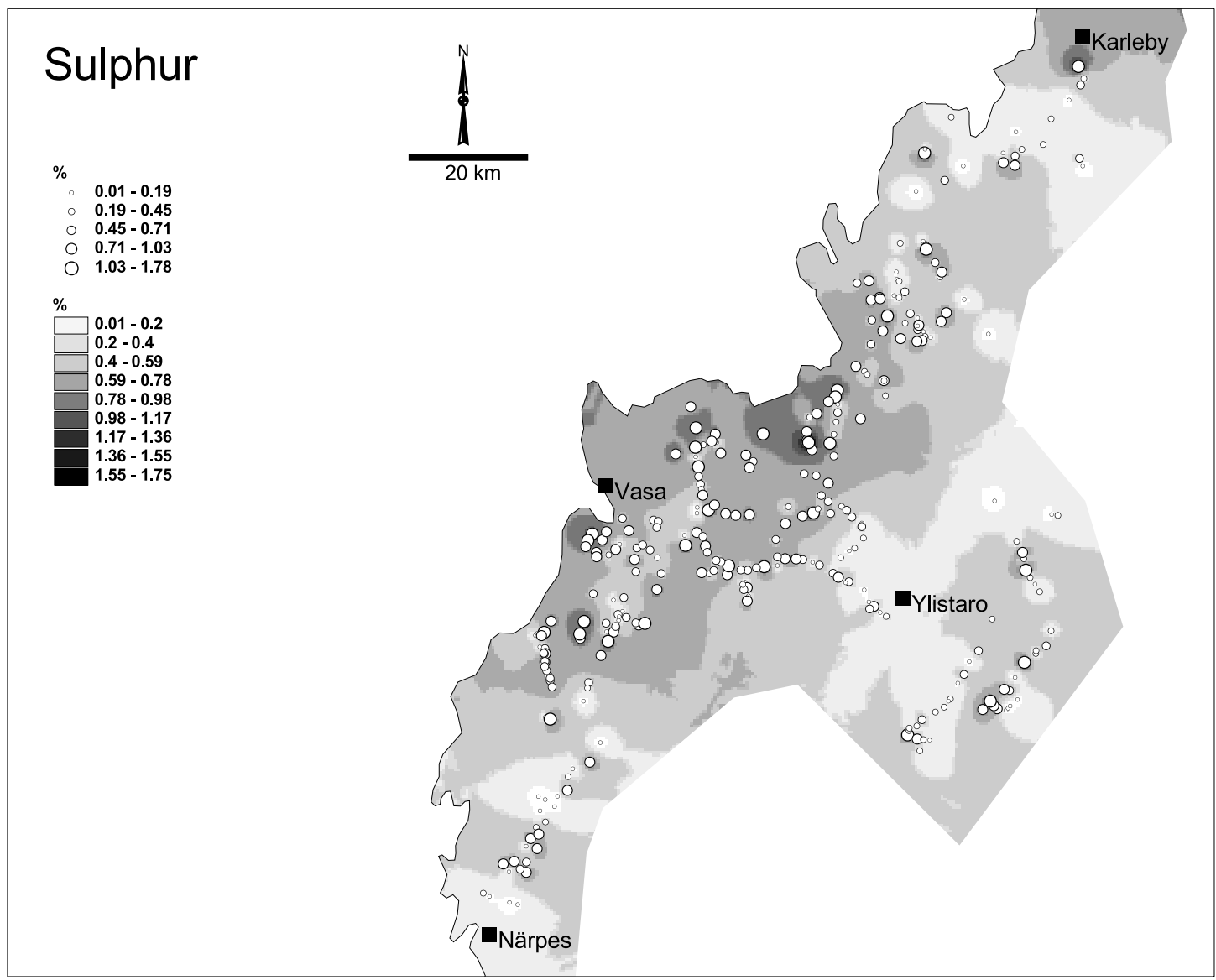

Fig. 3. Spatial distribution of sulphur in fine-grained sediments.

similar sediments by Deng et al. (1998). This shows that these metals exist predominantly in aqua regia extractable phases. Such phases may include sulphides, organic substances and several types of sheet silicates (Öborn 1991, Räisänen et al. 1992, Åström and Björklund 1997). Secondary $\mathrm{Fe}$ and Mn oxides, which are powerful traps of trace metals in oxidising environments, are unimportant in these strongly reducing sediments.

There was, as previously discussed by Åström and Björklund (1997), an inverse or only a weakly positive Spearman correlation between the aqua regia extractable metal concentrations and the total $\mathrm{S}$ and $\mathrm{C}$ concentrations in the fine-grained sediments $\left(r_{S}=-0.28\right.$ to 0.20$)$. Hence, metal concen- trations in sediment samples rich in sulphides and/ or organic matter were not significantly higher than those in samples poor in these substances. Conversely, the Spearman correlations between the concentrations of metals and fine materials (clay and fine silt) in the sediments were high, in particular for the "total" metal concentrations (not shown) but also for the aqua regia extractable ones (Fig. 4 and Table 1). Thus, as the sediment becomes finer, the metal concentration in general increases, which is a common and well known phenomenon largely explained by data closure (i.e. when there is an increase in resistant "coarse grained" minerals such as quartz and feldspars in the sediment, the fine-fraction component contain- 
Åström, M. \& Rönnback, K. Concentration levels of sulphur and metals in fine-grained sediments

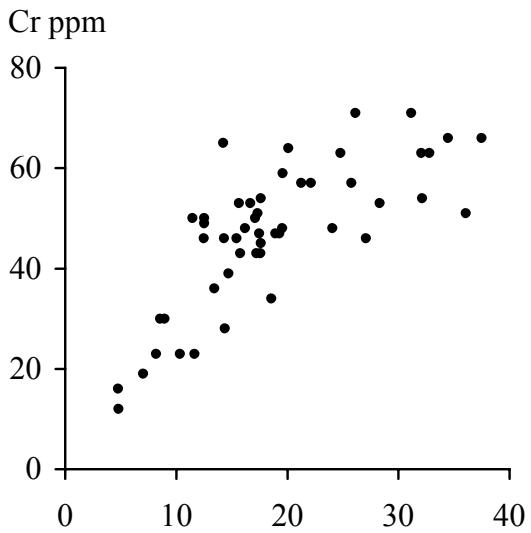

Clay $(<2 \mu \mathrm{m})$, volyme $\%$

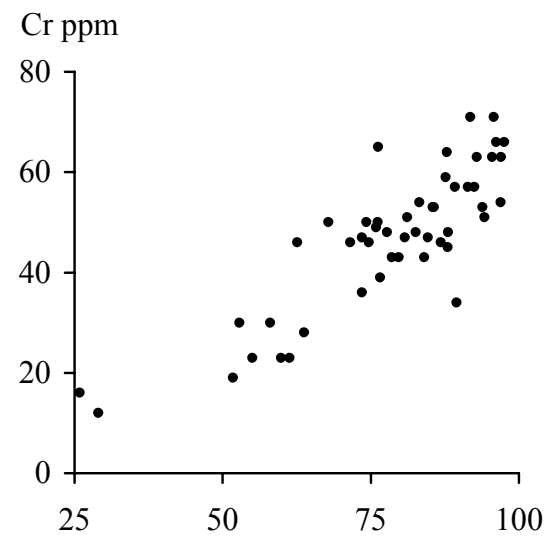

Fine silt $(<20 \mu \mathrm{m})$, volyme $\%$

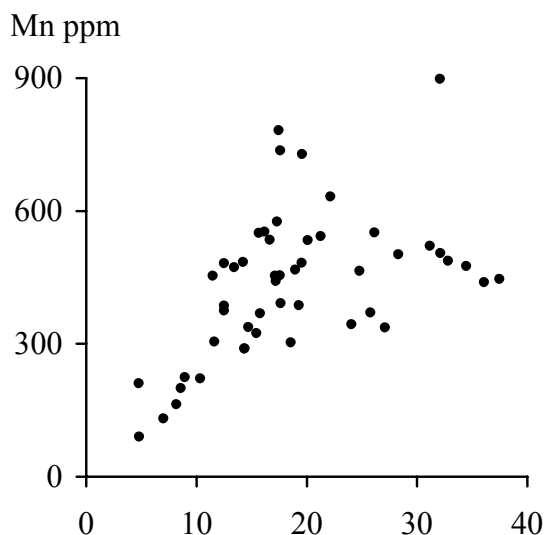

Clay $(<2 \mathrm{~mm})$, volyme $\%$
Mn ppm

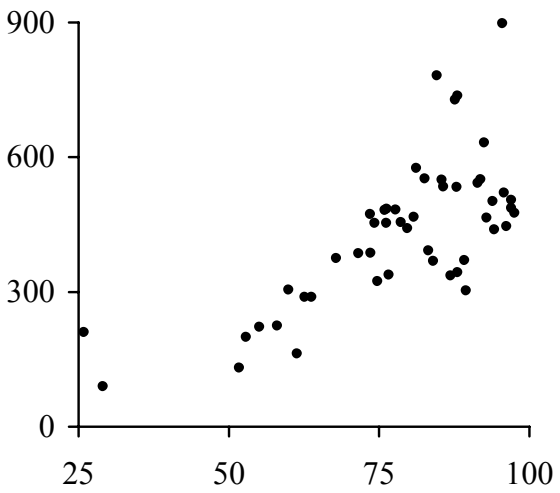

Fine silt $(<20 \mathrm{~mm})$, volyme $\%$

Fig. 4. Plots of grain size versus aqua regia extractable concentrations of $\mathrm{Cr}$ and $\mathrm{Mn}$ in 50 samples of finegrained sediments.

ing a majority of the first-row transition metals increases). Hence, there are evidence that: (1) fine particles of common minerals (e.g. mica, chlorite, kaolinite, amphibole, swelling clay minerals) consist the major carriers of first-row transition metals in the sediments and, (2) metal sulphides and organic compounds carries only minor parts of the total load of first-row transition metals in the sediments.
The recorded maximum concentrations of aqua regia extractable metals in the fine-grained sediments were well below the limit values for soil contamination (Table 1). Hence, the metal levels would not be expected to be harmful to the environment. However, drainage water from AS soils developed in these sediments is acidic and carries an abundance of $\mathrm{Co}, \mathrm{Cu}, \mathrm{Mn}, \mathrm{Ni}$ and $\mathrm{Zn}$. Therefore there must exist in the sediments a highly mobile 
Vol. 14 (2005): 14-23.

metal pool which is extensively leached at AS soil development, but which relative to the aqua regia extractable (or total) metal concentrations in the sediments is quantitatively minor. It seems likely, that this metal pool is associated with sulphides and possibly to some extent with easily weathered and metal-rich aluminosilicates. Therefore, these metals (except Mn; see below) are expected to be released spatially in a pattern resembling the spatial distribution of the $\mathrm{S}$ concentrations (Fig. 3).

In contrast to the other metals, Mn concentrations extracted by aqua regia are positively correlated to those released upon oxidation of the sediments (Åström 1998). Therefore, the map shown in Fig. 5, representing aqua regia extractable Mn, is relevant as far as the Mn release from current (and future oxidation of potential) AS soils are concerned. Consequently, more abundant Mn leaching into sensitive watercourses can be expected from the AS soils in the central (in particular the central-eastern) and southernmost parts of the area than from those in the north and in a rather broad zone extending south of Vasa (Fig. 5). The reason for this spatial pattern is unknown. It is however not directly related to the till geochemistry, since metal concentrations in nearby samples of fine-grained sediments and till were low $\left(\mathrm{r}_{\mathrm{S}}=\right.$ 0.19-0.47, Table 2).

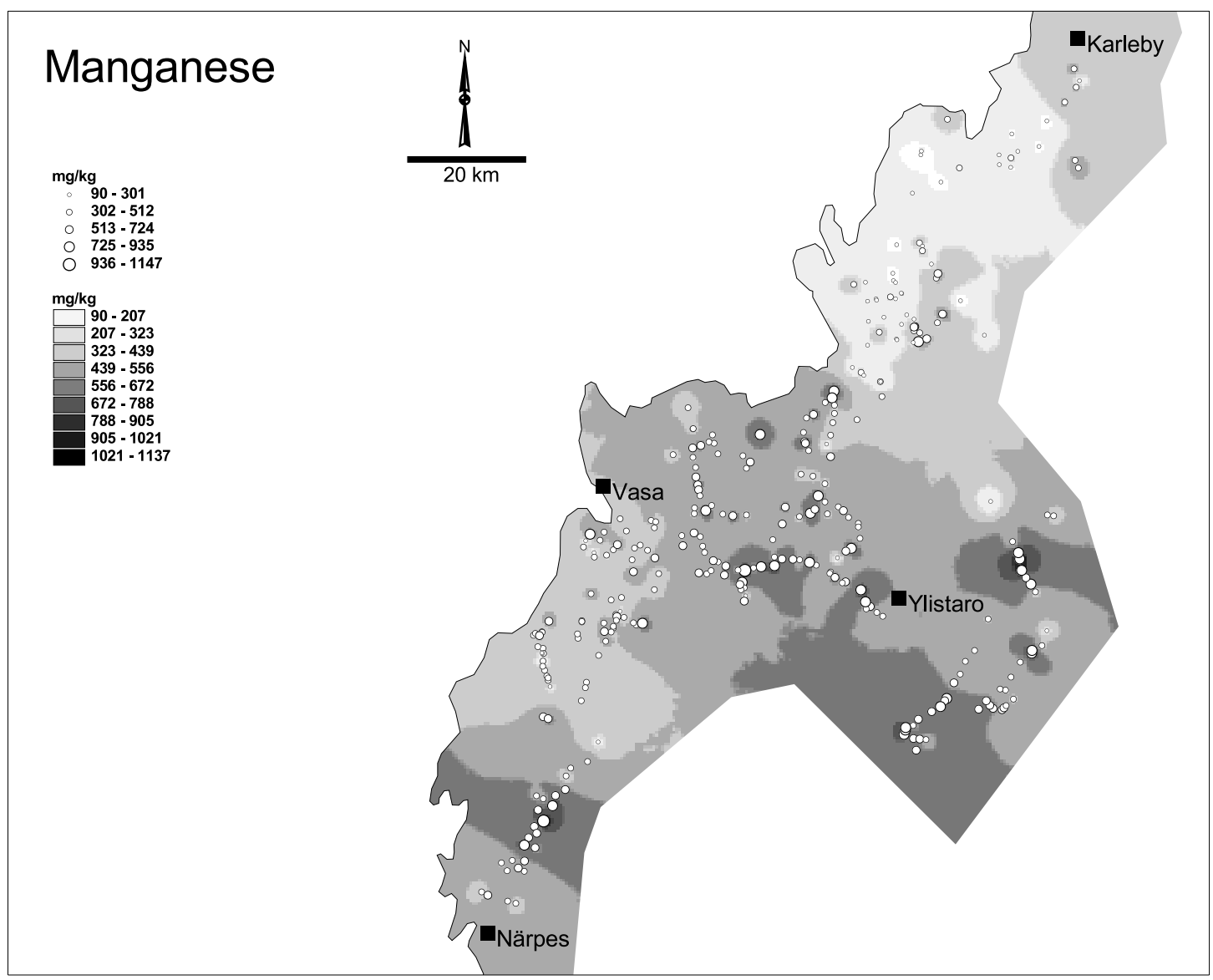

Fig. 5. Spatial distribution of Mn in fine-grained sediments. 
Åström, M. \& Rönnback, K. Concentration levels of sulphur and metals in fine-grained sediments

Table 2. Spearman rank correlation coefficients of element concentrations in fine-grained sediments and the clay fraction of the sediments (second column), the fine silt fraction of the sediments (third column), the elevation of the sampling sites (0-44 m a.s.l.) (fourth column), and the corresponding concentration in the $<0.06 \mathrm{~mm}$ fraction of paired till samples (fifth column). The critical value (95\% level of confidence) for the correlations with grain size is $0.28(n=50)$.

\begin{tabular}{lcccc}
\hline & $\begin{array}{l}\text { Clay } \\
<2 \mu \mathrm{m} \\
\mathrm{n}=50\end{array}$ & $\begin{array}{l}\text { Fine silt } \\
<20 \mu \mathrm{m} \\
\mathrm{n}=50\end{array}$ & $\mathrm{n}=317$ & $\mathrm{~T}$ \\
\hline $\mathrm{Ti}$ & 0.82 & 0.83 & 0.28 & $\mathrm{n}=258$ \\
$\mathrm{~V}$ & 0.72 & 0.78 & 0.15 & 0.22 \\
$\mathrm{Cr}$ & 0.74 & 0.78 & 0.22 & 0.39 \\
$\mathrm{Mn}$ & 0.55 & 0.65 & 0.35 & 0.34 \\
$\mathrm{Fe}$ & 0.70 & 0.76 & 0.14 & 0.19 \\
$\mathrm{Co}$ & 0.65 & 0.72 & 0.23 & 0.21 \\
$\mathrm{Ni}$ & 0.69 & 0.72 & 0.10 & 0.47 \\
$\mathrm{Cu}$ & 0.75 & 0.77 & 0.04 & 0.39 \\
$\mathrm{Zn}$ & 0.68 & 0.72 & 0.14 & 0.35 \\
$\mathrm{~S}$ & -0.19 & -0.14 & -0.21 & - \\
$\mathrm{C}$ & -0.24 & -0.15 & -0.13 & - \\
\hline
\end{tabular}

\section{Conclusions}

The fine-grained sediments on the coastal plains of western central Finland are overall rich in S (sulphides) which upon oxidation, following artificial drainage, causes widespread soil acidification (AS soil development). In contrast, the extensive release of several metals $(\mathrm{Co}, \mathrm{Cu}, \mathrm{Mn}, \mathrm{Ni}, \mathrm{Zn})$ in these acidified soils is not due to high natural or anthropogenic metal levels in the soils and their parent materials, but to an as yet unquantified inherent highly mobile metal pool. Spatial-distribution maps highlight areas of elevated $\mathrm{S}$ and $\mathrm{Mn}$ concentrations, where it is likely that ditching and subsequent oxidation will result in an exceptionally large release of protons and Mn respectively. These maps can be directly used in environmental assessment and as a basis for characterising the threat of potential and actual AS soils of the area.

Acknowledgements. This study was financially supported by Ella och Georg Ehrnrooths Stiftelse, Svenska Kulturfonden, Stiftelsen för Åbo Akademi Forskningsinstitut and Renlunds Stiftelse.

\section{References}

Åström, M. 1998. Mobility of Al, Co, Cr, Cu, Fe, Mn, Ni and $\mathrm{V}$ in sulphide-bearing sediments exposed to atmospheric $\mathrm{O}_{2}$ : an experimental study. Environmental Geology 36: 219-226.

Åström, M. \& Åström, J. 1997. Geochemistry of stream water in a catchment in Finland affected by sulphidic fine sediments. Applied Geochemistry 12: 593-605.

Åström, M. \& Björklund, A. 1997. Geochemistry and acidity of sulphide-bearing postglacial sediments of western Finland. Environmental Geochemistry and Health 19: 155-164.

Åström, M. \& Spiro, B. 2000. Impact of isostatic uplift and ditching of sulfidic sediments on the hydrochemistry of major and trace elements and sulfur isotope ratios in streams, western Finland. Environmental Science and Technology 34: 1182-1188.

Berner, R.A. 1984. Sedimentary pyrite formation: An update. Geochimica at Cosmochimica Acta 48: 605-615.

Deng, H., Åström, M. \& Björklund, A. 1998. Geochemical and mineralogical properties of sulfide-bearing finegrained sediments in Finland. Environmental Geology 36: 37-44.

Dent, D. 1980. Acid sulphate soils: morphology and prediction. Journal of Soil Science 31: 87-99.

Eden, P., Weppling, K. \& Jokela, S. 1999. Natural and landuse induced load of acidity, metals, humus and suspended matter in Lestijoki, a river in western Finland. Boreal Environment Research 4: 31-43.

Erviö, R. \& Palko J. 1984. Macronutrient and micronutrient 
Vol. 14 (2005): 14-23.

status of cultivated acid sulphate soils at Tupos, Finland. Annales Agriculturae Fenniae 23: 121-134.

Georgala, D. 1980. Paleoenvironmental studies of postglacial black clays in north-eastern Sweden. Stockholm contributions in geology 36: 93-151.

Gill, R. (ed). 1997. Modern analytical geochemistry, Longman, Harlow. 329 p.

Kawalec, A. 1973. World distribution of acid sulphate soils. In: Dost, H. (ed.) Proceedings of the International Symposium on Acid Sulphate Soils. International Institute for Land Reclamation and Improvement, Wageningen, the Netherlands. p. 292-295.

Kjellman, J. \& Hudd, R. 1996. Changed length-at-age of burbot, Lola lota, from an acidified estuary in the Gulf of Bothnia. Environmental Biology of Fisheries 45: 6573.

Lahermo, P., Väänänen, P., Tarvainen, T. \& Salminen, R. 1996. Geochemical atlas of Finland, part 3: Environmental geochemistry - stream waters and sediments. Geological Survey of Finland, Esbo, Finland. 149 p.

Lehtinen, M., Nurmi, P. \& Rämö, T. 1998. Suomen kallioperä. Geological Society of Finland, Helsinki. 375 p. (in Finnish).

Ministry of Social Affairs and Health 1994. Decision of the Ministry of Social Affairs and Health No 74. Helsingfors, Finland. $43 \mathrm{p}$.

Öborn, I. 1991. Some effects of chemical weathering in three cultivated acid sulfate soils in Sweden. In: Wright, R.J. et al. (eds.). Plant-soil interactions at low pH. Kluwer Academic Publisher, Dordrecht. Developments in Plant and Soil Sciences 45: 55-63.

Österholm, P. \& Åström, M. 2002. Spatial trends and losses of major and trace elements in agricultural acid sulphate soils distributed in the artificially drained Rintala area, W. Finland. Applied Geochemistry 17: 12091218.

Palko, J. 1994. Acid sulphate soils and their agricultural and environmental problems in Finland. Ph.D. thesis, University of Oulu, Finland. $58 \mathrm{p}$.

Palko, J. \& Yli-Halla, M. 1993. Assessment and management of acidity release upon drainage of acid sulphate soils in Finland. In: Dent, D.L. \& van Mensvoort, M.E.F. (eds.). Selected papers of the Ho Chi Minh City symposium on acid sulphate soils. International Institute for Land Reclamation and Improvement Publication 53. p. 411-418.

Papunen, H. 1968. On the sulphides in the sediments of the Bothnian Sea. Bulletin of the Geological Survey of Finland 40: 51-57.

Räisänen, M.-L., Tenhola, M. \& Mäkinen, J. 1992. Relationship between mineralogy and the physico-chemical properties of till in central Finland. Bulletin of the Geological Society of Finland 64: 35-58.

van Breemen, N. 1973. Soil forming process in acid sulphate soils. In: Dost, H. (ed.). Acid sulphate soils. International Institute for Land Reclamation and Improvement Publication 18. p. 66-130.

Weppling, K. 1993. Hydrochemical factors affecting the neutralization demand in acid sulphate waters. Vatten 49: 161-170.

Weppling, K., Innanen, M. \& Jokela, S. 1999. Life Lestijoki - managing acid sulphate soils. WWW Finland Report No 11. Helsinki. 63 p.

Wiklander, L. \& Hallgren, G. 1949. Studies on gyttja soils: Distribution of different sulfur and phosphrous forms and of iron, manganese and calcium carbonate in a profile from Kungsängen. The Annals of the Royal Agricultural College of Sweden 16: 811-827.

Wiklander, L., Hallgren, G. \& Jonsson, E. 1950. Studies on gyttja soils: rate of sulfur oxidation. The Annals of the Royal Agricultural College of Sweden 17: 425-440.

Yli-Halla, M. 1997. Classification of acid sulphate soils in Finland according to Soil Taxonomy and the FAO/ Unesco legend. Agricultural and Food Science in Finland 6: 247-258.

Yli-Halla, M., Puustinen, M. \& Koskiaho, J. 1999. Area of cultivated acid sulfate soils in Finland. Soil Use and Management 15: 62-67.

Wik, S. 2000. Regionala metallhaltsmönster och deras orsaker i finkorniga sulfidrika sediment $i$ Österbotten, västra centrala Finland. M.Sc. Thesis, Åbo Akademi University, Åbo, Finland. 52 p. (in Swedish). 